\title{
Tedarik Zincirinde Kamçı Etkisini Oluşturan Faktörlerin Simülasyon Programı ile Analizi
}

\author{
Analysis of the Factors that Lead to Bullwhip Effect in the Supply \\ Chain with a Simulation Program
}

\section{Doç. Dr. Aşkın Özdağoğlu}

\section{Öz}

Tedarik zinciri son kullanıcının ihtiyaçlarını karşılamak amacına yönelik olarak pek çok üyeden oluşan karmaşık bir yapıdır. Bu zincirde yer alan üyeler arttıkça bilgi bozulması yaşanmakta ve literatürde kamçı veya kırbaç etkisi olarak açıklanan stok dalgalanmaları ortaya çıkmaktadır. Bu çalışmanın amacı, tedarik zincirinin Stella 9.1.4. simülasyon programı kullamılarak modellenmesi ve kamçı etkisine yol açan faktörlerin bu model içerisinde analiz edilmesidir.

Anahtar Kelimeler: Tedarik Zinciri, Kamçı Etkisi, Stella

\begin{abstract}
Supply chain is a complex structure that consists a lot of members for meeting the end user's requirements. Misinformation has been realized in this chain when the members increased. This leads to stock fluctuations called as bullwhip effect in the literature. In this study, supply chain will be modelled by using Stella 9.1.4. simulation program and factors that give rise to bullwhip effect will be analyzed.
\end{abstract}

Keywords: Supply Chain, Bullwhip Effect, Stella

\section{Giriş}

Tedarik zinciri son kullanıcının ihtiyaçlarını karşılamak amacına yönelik olarak pek çok üyeden oluşan karmaşık bir yapıdır. Bu zincirde yer alan üyeler arttıkça bilgi bozulması yaşanmaktadır çünkü müşterinin gerçek talebini sadece tedarik zincirinin son halkası olan perakendeci bilmektedir. Tedarik zinciri içinde yer alan diğer halkalar olan toptanc1, dağıtıcı ve üretici unsurları ise kendilerine gelen sipariş bilgilerine dayanarak üretim ve satın alma planlarını hazırlamaktadırlar. Özellikle üretici bu zincirin ilk halkası olduğu için belirsizliklerden daha fazla etkilenmektedir. Örnek vermek gerekirse, müşteri talebi on birim arttığında, perakendeci talebin daha da artacağ 1 düşüncesiyle tedarik zincirinde kendisinden bir önceki halka olan toptancıya olan siparişini onbeş birim arttırmaktadır. Toptancı da bu artışı yirmi birim olarak siparişine yansıtmakta, dağıtıcı da herşeyin başlangıcı olan üreticiye olan siparişinde yirmibeş birim artış yapmaktadır. Bu aşırı üretim tüm zincir boyunca gerçek talebe uygun olmadığından dolayı stoklarda şişmeye yol açmakta ve tedarik zincirindeki tüm üyelerin stoklama maliyetlerini arttırmaktadır. Stokların şişmesi nedeniyle bu sefer girilen siparişler gerçek talepten daha az olmakta ve fabrikanın üretimi durdurmasına kadar giden sorunlara yol açmaktadır. Bu olay literatüre kamçı veya kırbaç etkisi olarak girmiştir.

Doç. Dr. Aşkın Özdağoğlu, Dokuz Eylül Üniversitesi İşletme Fakültesi, askin.ozdagoglu@deu.edu.tr 
Bu çalışmada öncelikle kamçı etkisi ile ilgili olarak literatürde yer alan çalışmalara değinilecek, ardından tedarik zinciri kavramı hakkında bilgi verilecektir. Daha sonra kamçı etkisini ortaya koyan tedarik zinciri oyunu açıklanacak ve üretici, dağıtıcı, toptancı ve perakendeciden oluşan dört üyeli tedarik zincirini temsil edecek şekilde dört kişi ile yapılan oyun denemesinin sonuçları verilecektir. Bu oyun yapısı temel alınarak tedarik zinciri Stella 9.1.4. simülasyon programı kullanılarak modellenecek ve kamçı etkisine yol açan faktörler bu model içerisinde analiz edilecektir.

\section{Literatür İncelemesi}

Kamçı etkisinin analizine yönelik literatürde pek çok çalışma bulunmaktadır. Kademe sayısı, dağıtım kanalları gibi tedarik zincirindeki yapısal faktörlerin zincirin dinamik performansını (örneğin kamçı etkisi) nasıl etkilediğini gösteren bir simülasyon yapılmıştır (Dominguez vd., 2015a). 383 gerçek müşteri - tedarikçi ikilisi incelenerek kamçı etkisinin kar marjları üzerindeki etkisi araştırılmıştır (Mackelprang vd., 2015). Farklı sipariş politikalarının ve talep eğilimlerinin yarattığı kamçı etkisi araştırılmıştır (Fu vd., 2015). Bilgi paylaşımının kamçı etkisi ve stok değişkenliği açısından kabul edilebilir bir performans düzeyine ulaşmayı nasıl mümkün kıldığını göstermek ve farklı sipariş politikalarını analiz etmek için simülasyon hazırlanmıştır (Costantino vd., 2015a). Üretici ve perakendeci arasında bilgi paylaşımının zamanlamasına bağlı olarak iki farklı işbirliği mekanizması incelenmiştir (Xu vd., 2015). Mevsimlik ürünlere yönelik olarak mevsimlik otoregresif hareketli ortalama süreci için teorik altyapı oluşturulmuş ve kamçı etkisi ölçülmüştür (Nagaraja vd., 2015). Talep düzeyinin otoregresif olup olmas1na göre kamçı etkisi incelenmiştir (Babai vd., 2015). Doğrusal olmayan sipariş politikalarının kamçı etkisi üzerinde yarattığı değişim araştırılmıştır (Wang vd., 2015). Çevrim süresinin tedarik zincirindeki stok değişkenliği üzerindeki etkisi araştırılmıştır (Hosoda vd., 2015). Dinamik tedarik ağında taşıma faaliyetlerinden kaynaklanan gecikmelerin etkisini azaltmaya yönelik olarak bir model önerilmiştir (Qiu vd., 2015). Kamçı etkisini azaltmak amacıyla Goldratt'in kısıtlar teorisine dayanan bir model geliştirilmiştir (Costas vd., 2015). Farklı tedarik zinciri yapıları deneysel tasarım ile analiz edilmiştir (Dominguez vd., 2015b). Tedarikçi siparişi zamanında karşılayamadığında ve teslimat süreleri uzadığında müşterinin buna tepkisi emniyet stok seviyesini arttırmak ve ihtiyaç duyduğu düzeyden daha fazla sipariş vermek şeklinde olmaktadır. Kıt malzemeye verilen bu tepki davranışsal ve duygusal olabilmektedir. Bu konuyu irdelemek amacıyla bira dağıtım oyunu ile ilgili deneysel tasarım yapilmıştır (Sterman ve Doğan, 2015).

Hem operasyonel performans (sipariş ve stok düzeyinin dengeli olması) hem de müşterilere sunulan hizmet düzeyi açısından stok kayıtlarının hatalı tutulmasının etkisi araştırılmıştır. Yapılan Anova analizi sonucunda, stok kayıtlarına ilişkin hataların tüm performans göstergeleri açısından temel belirleyici faktör olduğu bulunmuştur (Cannella vd., 2015).

Kamçı etkisinin sadece ürünün kendisinde değil ikame mallar üzerinde de oluşup oluşmadığ 1 incelenmiştir (Duan vd., 2015). Tek bir ürüne ait tedarik zincirinden farklı olarak birbirleri ile karşılıklı etkileşim içinde bulunan talebin fiyat esnekliği yüksek olan iki ürüne ait iki tedarik zincirinde kamçı etkisi araştırılmıştır. Bu çalışma sonucunda, ürünlerin birbirini ikame edebilme özelliğinden dolayı iki rakip tedarik zincirindeki karşıllıklı etkileşimin kamçı etkisini arttıracağı bulunmuştur. Bu etkinin azalması ürünlerin ikame oranlarının düşmesi ile mümkündür. İki tedarik zinciri ortak çalışıyorsa veya bu zincirlerin sunduğu ürünler birbirini tamamlayıcı ürünler ise kamçı etkisi azalmaktadır. Ürünlerin birbirini tamamlama oranı yüksek ise kamçı etkisi azalacaktır (Ma vd., 2015, s.822).

2008 yılında Lehman Brothers iflası ile başlayan ve onu takip eden finans dünyasındaki çöküşler imalat sektörünü de vurmuş ve üretimin düşmesine yol açmıştır. Bu tür bir olayın tedarik zincirinde yaratacağ 1 şok ve doğal olarak ortaya çıkacak kamçı etkisini araştırmak amacıyla tedarik zincirindeki yapısal, operasyonel ve davranışsal pek çok parametreyi içeren bir sistem dinamikleri modeli kurulmuştur (Udenio vd., 2015). Hiç bilgi paylaşımının olmaması ve tam bilgi paylaşımı şeklinde iki farklı senaryo açısından stok sistemleri incelenmiştir. Bu senaryolar için doğrusal regresyon modeli kullanılarak kamçı etkisinin farklı nedenleri araştırılmıştır. Çalışmada ayrıca karar vericiler açısından davranışsal analizler yapılmış ve bilgi paylaşımının yapıldığ 1 tedarik zincirlerinde beklenmedik durumlara karşı verilecek tepki konusunda karar vericilerin eğitilmesi gerektiği ve zincirin bir 
üyesi hata yapsa da zincirdeki üyelerin birbirini suçlamaması ve sorunu çözmek için işbirliği yapmaları gerektiği şeklinde önerilerde bulunulmuştur (Zhao ve Zhao, 2015). Talepte meydana gelebilecek beklenmedik dalgalanmalara daha hızlı yanıt verebilmek amaclyla mevcut tedarik zincirini çevikleştirmek için potansiyel tedarikçilerin pek çok farklı ölçüt açısından değerlendirilmesi gerekmektedir. Bu değerlendirmeleri yapan firma yetkililerinin öznel değerlendirmelerini sayısal değerlere dönüştürmek amacıyla bulanık analitik hiyerarşi süresi ve bulanık Topsis yöntemleri birlikte kullanılmış ve yöntemi değerlendirmek amacıyla kamçı etkisi ölçülmüştür (Lee vd., 2015). Üretim sürecindeki değişkenlikleri incelemek amacıyla kullanılan istatistiksel süreç kontrol kartları tedarik zinciri yapısına uyarlanmış ve talep kontrol kartları ile alt ve üst kontrol limitleri belirlenmiştir. Belirlenen bu alt ve üst kontrol limitlerine bağlı olarak karar kuralları oluşturulmuş ve kamçı etkisini azaltmak için kullanılan öngörümleme yöntemlerinden biri olan hareketli ortalama yöntemine alternatif olarak istatistiksel süreç kontrol öngörümleme yöntemi önerilmiştir. Ardından bu iki farklı öngörümleme yöntemine göre tedarik zinciri performansları karşılaştırılmıştır (Costantino vd., 2015b). Yine aynı çalışma grubu tarafından tedarik zinciri yapısına uyarlanmış istatistiksel süreç kontrol öngörümleme yöntemi, kamçı etkisini azaltmak için kullanılan öngörümleme yöntemlerinden biri olan hareketli ortalama yöntemi ve bir diğer zaman serisi modeli olan üssel düzeltim öngörümleme yöntemi karşılaştırılmıştır (Costantino vd., 2015c). Benzer şekilde bilgi paylaşımının yapılmadığg 1 tedarik zincirlerinde hareketli ortalama yöntemi kullanılarak sonuçlar değerlendirilmiştir (Ali vd., 2015). Bilgi paylaşımının yapılmadığı tedarik zincirlerinde faaliyetleri yürütmenin zorluğundan hareketle talep öngörümleme yapmak amaciyla benzer talep davranışlarına sahip olan müşterileri sınıflamak için veri madenciliği uygulanmıştır (Murray vd., 2015).

Tayvan'da 2009 yılı ilk 1000 firma listesinde yer alan elektronik sektöründeki firmalara odaklanılarak tedarik zincirinde işbirliği ile ilgili neden - sonuç ilişkisi kurulmuştur. Bu ilişkilerin oluşturulması ve faktörlerin önem düzeylerinin bulunması için çok ölçütlü karar verme yöntemlerinden biri olan Bulanık Dematel yönteminden yararlanılarak ikili karşılaştırma matrisleri oluşturulmuştur (Jeng, 2015). Üretim / İşlemler yönetimi için yapılan araştırmalarda sistem dinamikleri yaklaşımının ve modelleme faaliyetle- rinin kullanılabileceği alanlar incelenmiş ve tedarik zinciri yönetimi, proje yönetimi ve süreç yönetimi alt başılıkları açısından kullanımı ile ilgili teorik bir çerçeve çizilmiştir (Editorial, 2015). Tedarik zincirindeki olası riskleri tanımlamak ve risk yönetiminde kullanılabilecek alternatif modeller arasında bir seçim yapabilmek amacıyla bir inceleme yapılmış ve risk türlerine göre stratejiler önerilmiştir (Blos vd., 2015). Tedarik zincirine koordinatör eklemenin finansal etkisini değerlendirmek amacıyla teslim edilecek malı bölerek tam zamanında teslimat anlaşması içeren bir maliyet modeli oluşturulmuş ve çeşitli parametreler üzerinde değiş̧iklikler yapılarak farklı senaryolar karşılaştırılmıştır (Masten ve Kim, 2015). Tedarik zinciri sistemlerinin arzu edilmeyen davranışı olan kamçı etkisinin kurumsal kaynak planlama sisteminden doğru talep bilgisinin çekilmesi ile azaltılabileceğinden hareketle senkronizasyonu sağlayan bir yönetim sistemi kurulmuş ve tüm teorik analizler simülasyon denemeleri ile test edilmiştir (Göksu vd., 2015).

Tüm bu güncel çalışmalardan da görüldügü üzere kamçı etkisi literatürdeki önemini korumakta ve azaltılmasına yönelik olarak pek çok farklı model önerilmektedir. İzleyen bölümde kamçı etkisi ve tedarik zinciri oyunu hakkında bilgi verilecektir.

\section{Kamçı Etkisi ve Tedarik Zinciri Oyunu}

Tedarik zinciri yönetimi ürün ve/veya hizmetlerde şekil faydası sağlamak için malzeme, bilgi ve kaynak akışlarının ileri ve geri yöndeki örgütlenmesini sağlama çabasıdır (Mangan vd., 2008, s.11). Tanımdaki önemli noktalara bakılacak olursa, sadece ileri yönde değil geri yönde de akış olduğu görülebilmektedir. Üreticiden son kullanıcıya doğru ileri yönde akış mevcut iken müşteriden de üreticiye doğru bir akış bulunmaktadır. Bunun temel nedeni, müşteriden gelen talep bilgisi doğrultusunda ham madde ve malzeme ihtiyaçlarının belirlenmesi ve ileri yönde akışı başlatmasıdır. Kamçı etkisinin ortaya çıkışı da bu geri yöndeki bilgi akışından kaynaklanmaktadır. Müşteri talebinde meydana gelen ufak bir değişim durgun suya atılan bir taş gibi dalgalanma yaratmakta ve tedarik zincirinde geriye doğru büyük sipariş artışlarına yol açmaktadır. Bu etkiyi göstermek amacıyla Kai Raemer tarafindan bir tedarik zinciri oyunu geliştirilmiştir (www.beergame.org , 27.05.2015). Oyunun anahatları şu şekildedir. Tedarik zinciri üretici, dağıtıcı, toptancı ve perakendeci olmak üzere dört 
üyeden oluşmaktadır. Zaman birimi olarak hafta kullanılmaktadır. Müşteri ihtiyacını karşılamak üzere perakendeciye gelmekte ve ürünü rafta bulduğunda ihtiyacını karşılamaktadır. Perakendeci stoklarını incelemekte ve tedarik zincirinde kendisinden bir önceki halka olan toptanciya sipariş vermektedir. Zincirdeki her üye için siparişin geliş süresi 2 haftadır. Toptancı da perakendecinin verdiği sipariş ve kendi stok seviyesine göre dağıtıcıya uygun miktarda sipariş geçmektedir. Dağıtıcı, toptancıdan gelen sipariş ve stok durumunu inceleyerek sipariş kararı vererek fabrikaya göndermektedir. Fabrika ise dağıtıcıdan gelen sipariş ve kendi stok düzeyini göz önüne alarak üretim bölümüne üretim emri geçmektedir. Fabrika için de partinin üretim süresi 2 haftadır. 2 haftalık bekleme süresinden dolayı tedarik zincirindeki her üyenin elinde sıfır maliyetli 15 adet stok bulunmaktadır. Oyun 40 hafta sürmektedir. Stoklama ve stoksuzluk maliyeti olmak üzere birbirine zit iki maliyet unsuru bulunmaktadır. Bir birim ürünü bir hafta elde tutmanın maliyeti $0,50 \mathrm{TL} /$ hafta'dır. Tedarik zincirindeki her üye kendisinden önce gelenin müşterisi olduğundan tüm üyeler için müşteri talebini zamanında karşılamama maliyeti 1 TL/Haftadır. Talep ne kadar geç olursa olsun karşılanacaktır. Gecikilen her hafta için stoksuzluk maliyeti önceki hafta maliyetlerinin üzerine eklenecektir. Oyunun amacı bu zıtlaşan maliyet unsurlarını birarada düşünerek toplam maliyeti en küçüklemektir. İlk hafta müşteri 5 birim ürün talep etmektedir. İlk 4 hafta boyunca bu değer sabittir. Beşinci haftada talep birdenbire $\% 80$ artış göstererek 9 birime çıkmaktadır. Bundan sonraki haftalarda ise bu 9 birimlik talep aynen devam etmektedir. Müșteri talebindeki bu değişim oyunda kamçı etkisini ortaya çıkarmakta ve zincirin üyeleri aşırı stok ve stoksuzluk arasında dalgalanma yaşamakta ve talep aynı düzeyde kaldığı için uzun vadede dengeye ulaşmaktadır. Üretici müşteri talep bilgisine en uzak üye olduğu için bu etki katlanarak artmaktadır. Oluşturulacak simülasyon modeline temel teşkil etmesi amaciyla 4 kişilik bir ekip ile oyun denenmiş ve sonuçlar kaydedilmiştir. Tedarik zincirinin üyeleri olan perakendeci, toptanc1, dağıtıcı ve son olarak üreticiye ait sonuçlar sirasiyla Tablo 1, 2, 3 ve 4'te sunulmuştur.

Tablo 1. Perakendeci Sonuçları

\begin{tabular}{|c|c|c|c|c|c|c|c|c|}
\hline 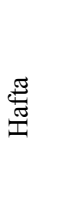 & 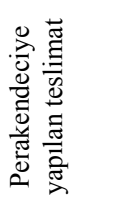 & 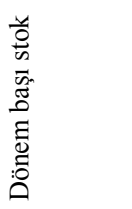 & $\begin{array}{l}\frac{\infty}{E} \\
\frac{0}{w} \\
\frac{0}{0} \\
\frac{0}{0} \\
0\end{array}$ & 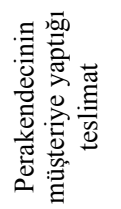 & 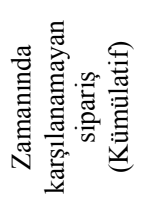 & 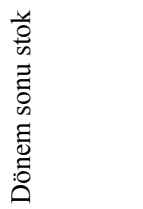 & 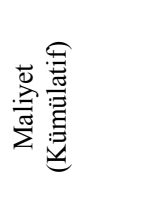 & 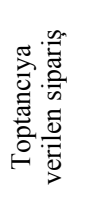 \\
\hline 0 & & & & & & 15 & & \\
\hline 1 & 0 & 15 & 5 & 5 & 0 & 10 & 5,0 & 10 \\
\hline 2 & 0 & 10 & 5 & 5 & 0 & 5 & 7,5 & 5 \\
\hline 3 & 10 & 15 & 5 & 5 & 0 & 10 & 12,5 & 5 \\
\hline 4 & 5 & 15 & 5 & 5 & 0 & 10 & 17,5 & 5 \\
\hline 5 & 5 & 15 & 9 & 9 & 0 & 6 & 20,5 & 4 \\
\hline 6 & 5 & 11 & 9 & 9 & 0 & 2 & 21,5 & $\overline{14}$ \\
\hline 7 & 4 & 6 & 9 & 6 & 3 & 0 & 24,5 & $\overline{4}$ \\
\hline 8 & 14 & 14 & 9 & 12 & 0 & 2 & 25,5 & $\overline{10}$ \\
\hline 9 & 4 & 6 & 9 & 6 & 3 & 0 & 28,5 & 10 \\
\hline 10 & 10 & 10 & 9 & 10 & 2 & 0 & 30,5 & 15 \\
\hline 11 & 10 & 10 & 9 & 10 & 1 & 0 & 31,5 & 3 \\
\hline 12 & 15 & 15 & 9 & 10 & 0 & 5 & 34,0 & 12 \\
\hline 13 & 3 & 8 & 9 & 8 & 1 & 0 & 35,0 & 12 \\
\hline 14 & 12 & 12 & 9 & 10 & 0 & 2 & 36,0 & 10 \\
\hline 15 & 12 & 14 & 9 & 9 & 0 & 5 & 38,5 & 5 \\
\hline 16 & 10 & 15 & 9 & 9 & 0 & 6 & 41,5 & 10 \\
\hline 17 & 5 & 11 & 9 & 9 & 0 & 2 & 42,5 & 10 \\
\hline
\end{tabular}


Tablo 1. Perakendeci Sonuçları (Devamı)

\begin{tabular}{|c|c|c|c|c|c|c|c|c|}
\hline 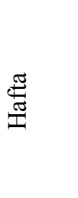 & 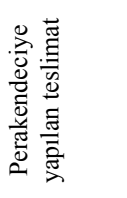 & 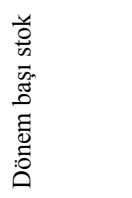 & 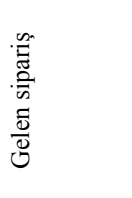 & 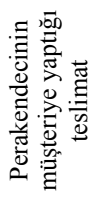 & 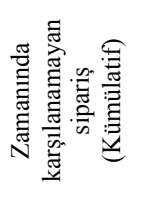 & 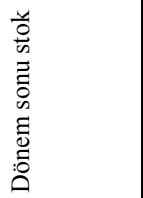 & 总害 & 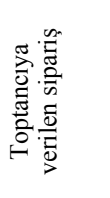 \\
\hline 18 & 10 & 12 & 9 & 9 & 0 & 3 & 44,0 & 8 \\
\hline 19 & 10 & 13 & 9 & 9 & 0 & 4 & 46,0 & 8 \\
\hline 20 & 8 & 12 & 9 & 9 & 0 & 3 & 47,5 & 14 \\
\hline 21 & 4 & 7 & 9 & 7 & 2 & 0 & 49,5 & 20 \\
\hline 22 & 5 & 5 & 9 & 5 & 6 & 0 & 55,5 & 20 \\
\hline 23 & 3 & 3 & 9 & 3 & 12 & 0 & 67,5 & 5 \\
\hline 24 & 0 & 0 & 9 & 0 & 21 & 0 & 88,5 & 10 \\
\hline 25 & 18 & 18 & 9 & 18 & 12 & 0 & 100,5 & 5 \\
\hline 26 & 9 & 9 & 9 & 9 & 12 & 0 & 112,5 & 15 \\
\hline 27 & 10 & 10 & 9 & 10 & 11 & 0 & 123,5 & 20 \\
\hline 28 & 15 & 15 & 9 & 15 & 5 & 0 & 128,5 & 5 \\
\hline 29 & 10 & 10 & 9 & 10 & 4 & 0 & 132,5 & 0 \\
\hline 30 & 25 & 25 & 9 & 13 & 0 & 12 & 138,5 & $\overline{0}$ \\
\hline 31 & 23 & 35 & 9 & $\overline{9}$ & 0 & 26 & 151,5 & 0 \\
\hline 32 & 0 & 26 & 9 & 9 & 0 & 17 & 160,0 & 5 \\
\hline 33 & 0 & 17 & 9 & 9 & 0 & 8 & 164,0 & 8 \\
\hline 34 & 5 & 13 & 9 & $\overline{9}$ & 0 & 4 & 166,0 & 10 \\
\hline 35 & 8 & 12 & 9 & 9 & 0 & 3 & 167,5 & 8 \\
\hline 36 & 10 & 13 & 9 & 9 & 0 & 4 & 169,5 & 6 \\
\hline 37 & 8 & 12 & 9 & 9 & 0 & 3 & 171,0 & 10 \\
\hline 38 & 6 & 9 & 9 & $\overline{9}$ & 0 & 0 & 171,0 & 10 \\
\hline 39 & 10 & 10 & 9 & $\overline{9}$ & 0 & 1 & 171,5 & 8 \\
\hline 40 & 10 & 11 & 9 & 9 & 0 & 2 & 172,5 & 10 \\
\hline
\end{tabular}

Tablo 2. Toptancı Sonuçları

\begin{tabular}{|c|c|c|c|c|c|c|c|c|}
\hline 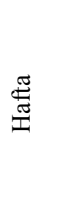 & 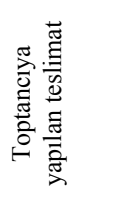 & 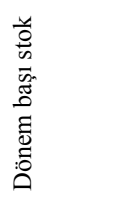 & 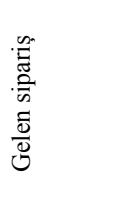 & 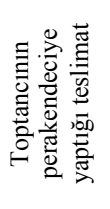 & 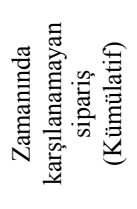 & 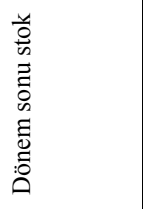 & 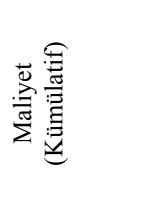 & 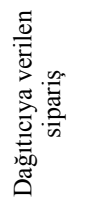 \\
\hline 0 & & & & & & 15 & & \\
\hline 1 & 0 & 15 & 10 & 10 & 0 & 5 & 2,5 & 5 \\
\hline 2 & 0 & 5 & 5 & 5 & 0 & 0 & 2,5 & 5 \\
\hline 3 & 5 & 5 & 5 & 5 & 0 & 0 & 2,5 & 15 \\
\hline 4 & 5 & 5 & 5 & 5 & 0 & 0 & 2,5 & 11 \\
\hline 5 & 10 & 10 & 4 & 4 & 0 & 6 & 5,5 & 12 \\
\hline 6 & 10 & 16 & 14 & 14 & 0 & 2 & 6,5 & 14 \\
\hline 7 & 3 & 5 & 4 & 4 & 0 & 1 & 7,0 & 7 \\
\hline 8 & 20 & 21 & 10 & 10 & 0 & 11 & 12,5 & 18 \\
\hline 9 & 16 & 27 & 10 & 10 & 0 & 17 & 21,0 & 17 \\
\hline 10 & 14 & 31 & 15 & 15 & 0 & 16 & 29,0 & 9 \\
\hline
\end{tabular}


Tablo 2. Toptancı Sonuçları (Devamı)

\begin{tabular}{|c|c|c|c|c|c|c|c|c|}
\hline$\underset{\overparen{\mathbb{J}}}{\stackrel{\mathbb{J}}{\pi}}$ & 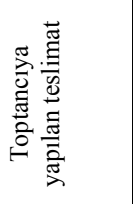 & 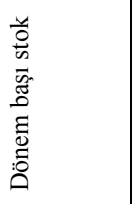 & 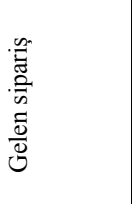 & 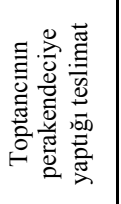 & 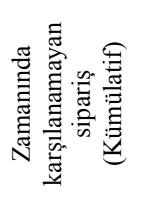 & 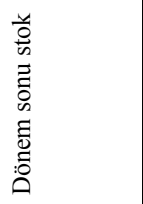 & 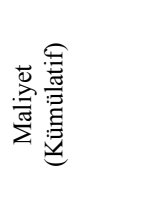 & 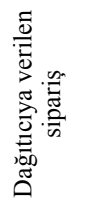 \\
\hline 11 & 7 & 23 & 3 & 3 & 0 & 20 & 39,0 & 21 \\
\hline 12 & 15 & 35 & 12 & 12 & 0 & 23 & 50,5 & 4 \\
\hline 13 & 15 & 38 & 12 & 12 & 0 & 26 & 63,5 & 1 \\
\hline 14 & 18 & 44 & 10 & 10 & 0 & 34 & 80,5 & 0 \\
\hline 15 & 1 & 35 & 5 & 5 & 0 & 30 & 95,5 & 0 \\
\hline 16 & 0 & 30 & 10 & 10 & 0 & 20 & 105,5 & $\underline{0}$ \\
\hline 17 & 0 & 20 & 10 & 10 & 0 & 10 & 110,5 & 2 \\
\hline 18 & 0 & 10 & 8 & 8 & 0 & 2 & 111,5 & 5 \\
\hline 19 & 2 & 4 & 8 & 4 & 4 & 0 & 115,5 & 3 \\
\hline 20 & 5 & 5 & 14 & 5 & 13 & 0 & 128,5 & $\underline{0}$ \\
\hline 21 & 3 & 3 & 20 & 3 & 30 & 0 & 158,5 & 18 \\
\hline 22 & 0 & 0 & 20 & 0 & 50 & 0 & 208,5 & 20 \\
\hline 23 & 18 & 18 & 5 & 18 & 37 & 0 & 245,5 & 30 \\
\hline 24 & 9 & 9 & 10 & 9 & 38 & 0 & 283,5 & 30 \\
\hline 25 & 10 & 10 & 5 & 10 & 33 & 0 & 316,5 & 30 \\
\hline 26 & 15 & 15 & 15 & 15 & 33 & 0 & 349,5 & 30 \\
\hline 27 & 10 & 10 & 20 & 10 & 43 & 0 & 392,5 & 30 \\
\hline 28 & 25 & 25 & 5 & 25 & 23 & 0 & 415,5 & 17 \\
\hline 29 & 45 & 45 & 0 & 23 & 0 & 22 & 426,5 & 4 \\
\hline 30 & 25 & 47 & 0 & 0 & 0 & 47 & 450,0 & 0 \\
\hline 31 & 30 & 77 & 0 & 0 & 0 & 77 & 488,5 & 0 \\
\hline 32 & 12 & 89 & 5 & 5 & 0 & 84 & 530,5 & 0 \\
\hline 33 & 0 & 84 & 8 & 8 & 0 & 76 & 568,5 & 0 \\
\hline 34 & 0 & 76 & 10 & 10 & 0 & 66 & 601,5 & 0 \\
\hline 35 & 0 & 66 & 8 & 8 & 0 & 58 & 630,5 & 0 \\
\hline 36 & 0 & 58 & 6 & 6 & 0 & 52 & 656,5 & $\underline{0}$ \\
\hline 37 & 0 & 52 & 10 & 10 & 0 & 42 & 677,5 & 0 \\
\hline 38 & 0 & 42 & 10 & 10 & 0 & 32 & 693,5 & 0 \\
\hline 39 & 0 & 32 & 8 & 8 & 0 & 24 & 705,5 & 0 \\
\hline 40 & 0 & 24 & 10 & 10 & 0 & 14 & 712,5 & 0 \\
\hline
\end{tabular}


Tablo 3. Dağıtıcı Sonuçları

\begin{tabular}{|c|c|c|c|c|c|c|c|c|}
\hline$\underset{\mathbb{E}}{\stackrel{\mathbb{E}}{I}}$ & 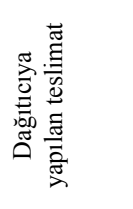 & 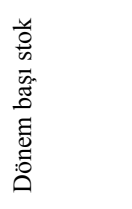 & 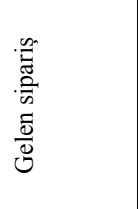 & 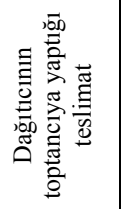 & 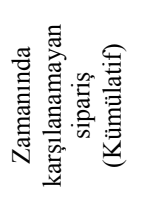 & 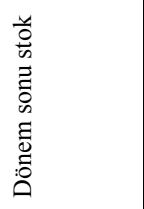 & 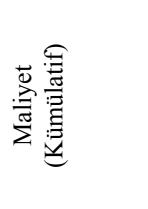 & 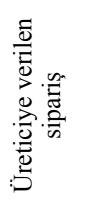 \\
\hline 0 & & & & & & 15 & & \\
\hline 1 & 0 & 15 & 5 & 5 & 0 & 10 & 5,0 & 5 \\
\hline 2 & 0 & 10 & 5 & 5 & 0 & 5 & 7,5 & 10 \\
\hline 3 & 5 & 10 & 15 & 10 & 5 & 0 & 12,5 & 20 \\
\hline 4 & 10 & 10 & 11 & 10 & 6 & 0 & 18,5 & 10 \\
\hline 5 & 3 & 3 & 12 & 3 & 15 & 0 & 33,5 & 10 \\
\hline 6 & 20 & 20 & 14 & 20 & 9 & 0 & 42,5 & 15 \\
\hline 7 & 17 & 17 & 7 & 16 & 0 & 1 & 43,0 & 10 \\
\hline 8 & 13 & 14 & 18 & 14 & 4 & 0 & 47,0 & 15 \\
\hline 9 & 7 & 7 & 17 & 7 & 14 & 0 & 61,0 & 20 \\
\hline 10 & 15 & 15 & 9 & 15 & 8 & 0 & 69,0 & 20 \\
\hline 11 & 15 & 15 & 21 & 15 & 14 & 0 & 83,0 & 15 \\
\hline 12 & 25 & 25 & 4 & 18 & 0 & 7 & 86,5 & 5 \\
\hline 13 & 20 & 27 & 1 & 1 & 0 & 26 & 99,5 & 0 \\
\hline 14 & 5 & 31 & 0 & 0 & 0 & 31 & 115,0 & 0 \\
\hline 15 & 0 & 31 & 0 & 0 & 0 & 31 & 130,5 & 0 \\
\hline 16 & 0 & 31 & 0 & 0 & 0 & 31 & 146,0 & 0 \\
\hline 17 & 0 & 31 & 2 & 2 & 0 & 29 & 160,5 & 0 \\
\hline 18 & 0 & 29 & 5 & 5 & 0 & 24 & 172,5 & 0 \\
\hline 19 & 0 & 24 & 3 & 3 & 0 & 21 & 183,0 & 0 \\
\hline 20 & 0 & 21 & 0 & 0 & 0 & 21 & 193,5 & 5 \\
\hline 21 & 0 & 21 & 18 & 18 & 0 & 3 & 195,0 & 10 \\
\hline 22 & 5 & 8 & 20 & 8 & 12 & 0 & 207,0 & 15 \\
\hline 23 & 10 & 10 & 30 & 10 & 32 & 0 & 239,0 & 25 \\
\hline 24 & 15 & 15 & 30 & 15 & 47 & 0 & 286,0 & 25 \\
\hline 25 & 10 & 10 & 30 & 10 & 67 & 0 & 353,0 & 30 \\
\hline 26 & 25 & 25 & 30 & 25 & 72 & 0 & 425,0 & 25 \\
\hline 27 & 45 & 45 & 30 & 45 & 57 & 0 & 482,0 & 30 \\
\hline 28 & 25 & 25 & 17 & 25 & 49 & 0 & 531,0 & 25 \\
\hline 29 & 30 & 30 & 4 & 30 & 23 & 0 & 554,0 & 10 \\
\hline 30 & 25 & 25 & 0 & 23 & 0 & 2 & 555,0 & 5 \\
\hline 31 & 10 & 12 & 0 & 0 & 0 & 12 & 561,0 & 0 \\
\hline 32 & 5 & 17 & 0 & 0 & 0 & 17 & 569,5 & 0 \\
\hline 33 & 0 & 17 & 0 & 0 & 0 & 17 & 578,0 & 0 \\
\hline 34 & 0 & 17 & 0 & 0 & 0 & 17 & 586,5 & 0 \\
\hline 35 & 0 & 17 & 0 & 0 & 0 & 17 & 595,0 & 0 \\
\hline 36 & 0 & 17 & 0 & 0 & 0 & 17 & 603,5 & 0 \\
\hline 37 & 0 & 17 & 0 & 0 & 0 & 17 & 612,0 & 0 \\
\hline 38 & 0 & 17 & 0 & 0 & 0 & 17 & 620,5 & 0 \\
\hline 39 & 0 & 17 & 0 & 0 & 0 & 17 & 629,0 & 0 \\
\hline 40 & 0 & 17 & 0 & 0 & 0 & 17 & 637,5 & 0 \\
\hline
\end{tabular}


Tablo 4. Üretici Sonuçları

\begin{tabular}{|c|c|c|c|c|c|c|c|c|}
\hline 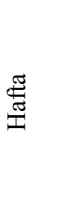 & 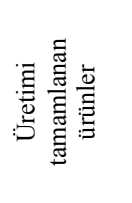 & 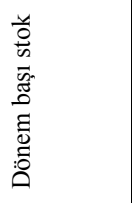 & 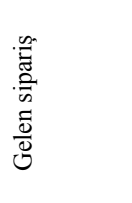 & 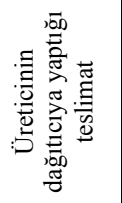 & 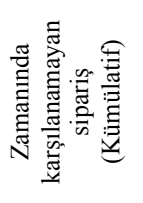 & 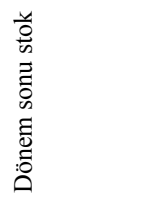 & 氞 & 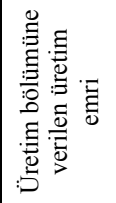 \\
\hline 0 & & & & & & 15 & & \\
\hline 1 & 0 & 15 & 5 & 5 & 0 & 10 & 5,0 & 3 \\
\hline 2 & 0 & 10 & 10 & 10 & 0 & 0 & 5,0 & 20 \\
\hline 3 & 3 & 3 & 20 & 3 & 17 & 0 & 22,0 & 20 \\
\hline 4 & 20 & 20 & 10 & 20 & 7 & 0 & 29,0 & 10 \\
\hline 5 & 20 & 20 & 10 & 17 & 0 & 3 & 30,5 & 7 \\
\hline 6 & 10 & 13 & 15 & 13 & 2 & 0 & 32,5 & 15 \\
\hline 7 & 7 & 7 & 10 & 7 & 5 & 0 & 37,5 & 15 \\
\hline 8 & 15 & 15 & 15 & 15 & 5 & 0 & 42,5 & 25 \\
\hline 9 & 15 & 15 & 20 & 15 & 10 & 0 & 52,5 & 25 \\
\hline 10 & 25 & 25 & 20 & 25 & 5 & 0 & 57,5 & 20 \\
\hline 11 & 25 & 25 & 15 & 20 & 0 & 5 & 60,0 & 15 \\
\hline 12 & 20 & 25 & 5 & 5 & 0 & 20 & 70,0 & 0 \\
\hline 13 & 15 & 35 & 0 & 0 & 0 & 35 & 87,5 & 0 \\
\hline 14 & 0 & 35 & 0 & 0 & 0 & 35 & 105,0 & 0 \\
\hline 15 & 0 & 35 & 0 & 0 & 0 & 35 & 122,5 & 0 \\
\hline 16 & 0 & 35 & 0 & 0 & 0 & 35 & 140,0 & 0 \\
\hline 17 & 0 & 35 & 0 & 0 & 0 & 35 & 157,5 & $\underline{0}$ \\
\hline 18 & 0 & 35 & 0 & 0 & 0 & 35 & 175,0 & 0 \\
\hline 19 & 0 & 35 & 0 & 0 & 0 & 35 & 192,5 & 0 \\
\hline 20 & 0 & 35 & 5 & 5 & 0 & 30 & 207,5 & 0 \\
\hline 21 & 0 & 30 & 10 & 10 & 0 & 20 & 217,5 & 5 \\
\hline 22 & 0 & 20 & 15 & 15 & 0 & 5 & 220,0 & 25 \\
\hline 23 & 5 & 10 & 25 & 10 & 15 & 0 & 235,0 & 50 \\
\hline 24 & 25 & 25 & 25 & 25 & 15 & 0 & 250,0 & 20 \\
\hline 25 & 50 & 50 & 30 & 45 & 0 & 5 & 252,5 & 30 \\
\hline 26 & 20 & 25 & 25 & 25 & 0 & 0 & 252,5 & 35 \\
\hline 27 & 30 & 30 & 30 & 30 & 0 & 0 & 252,5 & 30 \\
\hline 28 & 35 & 35 & 25 & 25 & 0 & 10 & 257,5 & 45 \\
\hline 29 & 30 & 40 & 10 & 10 & 0 & 30 & 272,5 & 0 \\
\hline 30 & 45 & 75 & 5 & 5 & 0 & 70 & 307,5 & 0 \\
\hline 31 & 0 & 70 & 0 & 0 & 0 & 70 & 342,5 & 0 \\
\hline 32 & 0 & 70 & 0 & 0 & 0 & 70 & 377,5 & 0 \\
\hline 33 & 0 & 70 & 0 & 0 & 0 & 70 & 412,5 & 0 \\
\hline 34 & 0 & 70 & 0 & 0 & 0 & 70 & 447,5 & 0 \\
\hline 35 & 0 & 70 & 0 & 0 & 0 & 70 & 482,5 & 0 \\
\hline 36 & 0 & 70 & 0 & 0 & 0 & 70 & 517,5 & 0 \\
\hline 37 & 0 & 70 & 0 & 0 & 0 & 70 & 552,5 & 0 \\
\hline 38 & 0 & 70 & 0 & 0 & 0 & 70 & 587.5 & 0 \\
\hline 39 & 0 & 70 & 0 & 0 & 0 & 70 & 622,5 & 0 \\
\hline 40 & 0 & 70 & 0 & 0 & 0 & 70 & 657,5 & 0 \\
\hline
\end{tabular}


Tablo 1, 2, 3 ve 4'teki değerler incelendiğinde müşteri talebinde bir defaya mahsus bir artış olmasına rağmen tedarik zinciri boyunca tüm üyelerin stok değerlerinde ciddi dalgalanmalar olduğu açıkça görülmektedir. Örnek vermek gerekirse, talep beșinci haftadan itibaren sürekli 9 birim olmasına rağmen üreticinin üretim bölümüne verdiği iş emirlerinde 45 birime kadar çıkıldığı ve stoklarında 70 birime ulaşıp eritilemediği görülmektedir. Müşteri talep bilgisine doğrudan ulaştığ 1 için perakendecinin toplam kümülatif maliyeti sadece 172,5 TL iken üretici için bu değer neredeyse 4 katı olup 657,5 TL'ye yükselmektedir.

$\mathrm{Bu}$ oyunun yapısı temel alınarak tedarik zincirinin simülasyonu yapılmış ve modelin gerçek durumu yansıtıp yansıtmadığı test edilmiștir. Ardından kamçı etkisini ortaya çıaran faktörler farklı senaryolar ile analize tabi tutulmuştur. İzleyen bölümde modelin oluşum aşamaları ve analizlere değinilecektir.

\section{Tedarik Zinciri Simülasyonu}

Bu aşamada ilk olarak tedarik zincirinin Stella simülasyon programında modeli kurulmuştur ${ }^{1}$. Kurulan model üretici, dağıtıcı, toptancı ve perakendeci olmak üzere dört üyeden oluşmaktadır. Tedarik zincirinin doğru bir şekilde modellenebilmesi için üreticiden son kullanıcıya kadar olan fiziki akışların yanısıra son kullanıcıdan üreticiye doğru olan bilgi akışını da sunacak unsurlar modele eklenmiştir. Modelin önemli unsurları aşağıda açıklanacaktır.

Tedarik zinciri içerisinde üretimi tetikleyerek fiziki akışları başlatan unsur son kullanıcının talebi olduguundan dolayı müşteri sipariş bilgisi ve kamçı etkisini incelemek üzere müşteri talebinde meydana gelecek değişimler için Stella simülasyon programı içerisinde "Converter” bileşeni kullanılmaktadır. Örnek "Converter” bileşeni Şekil l'de gösterilmiştir.

Fiziki akışları göstermek üzere Stella programında "Flow" bileșeninden yararlanılmıştır. Örnek "Flow" bileşeni Şekil 2'de görülmektedir.

1 Modelin oluşturulmasındaki katkılarından dolayı Makine Mühendisleri Odası İzmir Şubesi Sistem Dinamikleri Çalışma Grubuna ve Sayın Emre Göktepe’ye teşekkürü bir borç bilirim.
Şekil 2'de görüldüğü üzere "Required Inputs" alanında "PERAKENDECI BEKLEYEN SIPARIS" ifadesi görülmektedir. $\mathrm{Bu}$ ifadenin bulunmasının nedeni "Action Connector" kullanılarak bașka bir bileșen ile bağlantı yapılmış olmasıdır. Bu ifade aynı bileșene ilişkin pencerenin alt kısmında denklem oluşturulurken kullanılmıştır. Tedarik zincirindeki her bir üyenin stok miktarlarının takibi için "Stock" bileşeni kullanılmıştır. Örnek “Stock” bileşeni Şekil 3’te gösterilmiştir.

"Stock" bileșeni kullanıldığında model içerisindeki tüm bileşenler "Allowable Inputs" kısmında görülmekte ve denklem yazılırken kullanılabilmektedir.

Model içerisinde tedarik zincirindeki her bir üyeye ilişkin hedef stok düzeyleri, siparişte meydana gelen değişime tepkileri ve gelen siparişin zincirdeki bir sonraki üyeye teslim tarihleri "Converter" bileşenleri ile, tedarik zincirindeki her bir üyeye ilişkin sipariş girişleri, gönderilen siparişler ve teslimat işlemleri "Flow" bileșenleri ile gösterilmiştir. Tüm bu işlemlerin yapılması sonucunda oluşan model Şekil 4’te görülmektedir.

Hazırlanan model çalıştırılmadan önce çalışma süresi ile ilgili düzenleme yapmak için "Run" sekmesindeki "Run Specs" seçeneği açılır. "Run Specs" penceresinin görünümü Şekil 5 ’te sunulmuştur.

Model içerisindeki bileşenlerde teslim süreleri hafta olduğundan zaman birimi olarak hafta seçilmiş ve simülasyon süresi 52 hafta olarak belirlenmiştir.

Kamçı etkisine yol açan faktörlerin farklı senaryolar çalıştırılarak analiz edilebilmesi için "Interface" kısminda "Knob Input Device" ve "Slider Input Device" özellikleri kullanılmıştır. Bu faktörler, müşteri siparişinde meydana gelen değişim, tedarik zincirinde yer alan her bir üye için hafta bazında hedef stok değerleri, stok ayarlama oranları ve teslimat süreleridir. Başlangıç değeri olarak müşteri siparişindeki değişim " 0 ", tedarik zincirinde yer alan her bir üye için hafta bazında hedef stok değerleri "2 hafta", stok ayarlama oranlar1 " $\% 25$ " ve teslimat süreleri ile üretim süresi de "1 hafta" olarak belirlenmiştir. Farklı senaryoların çalıştırılabilmesi için müşteri siparişindeki değişim aralığ1 $[0 ; 50]$ olarak tanımlanmıştır. Müşteri siparişindeki değişim için oluşturulan "Knob Input Device" Şekil 6’da görülebilir. 


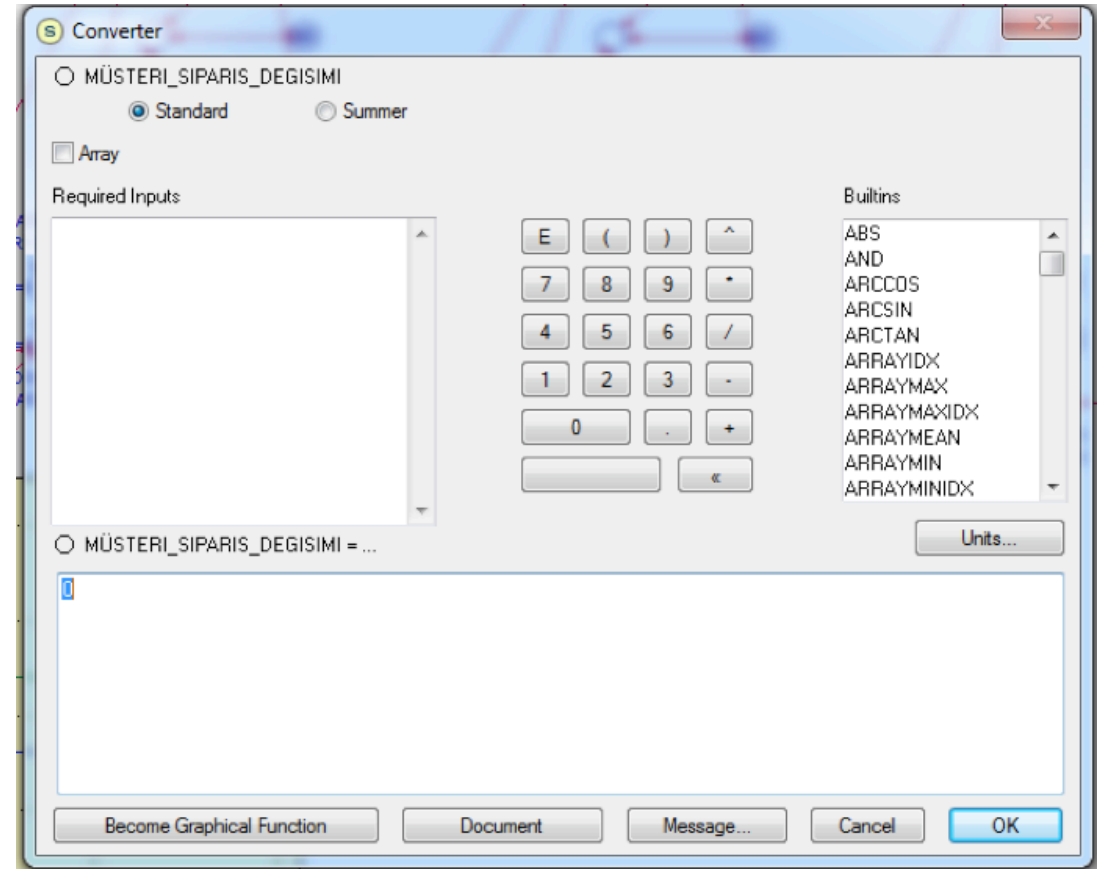

Şekil 1. Converter Bileşeni

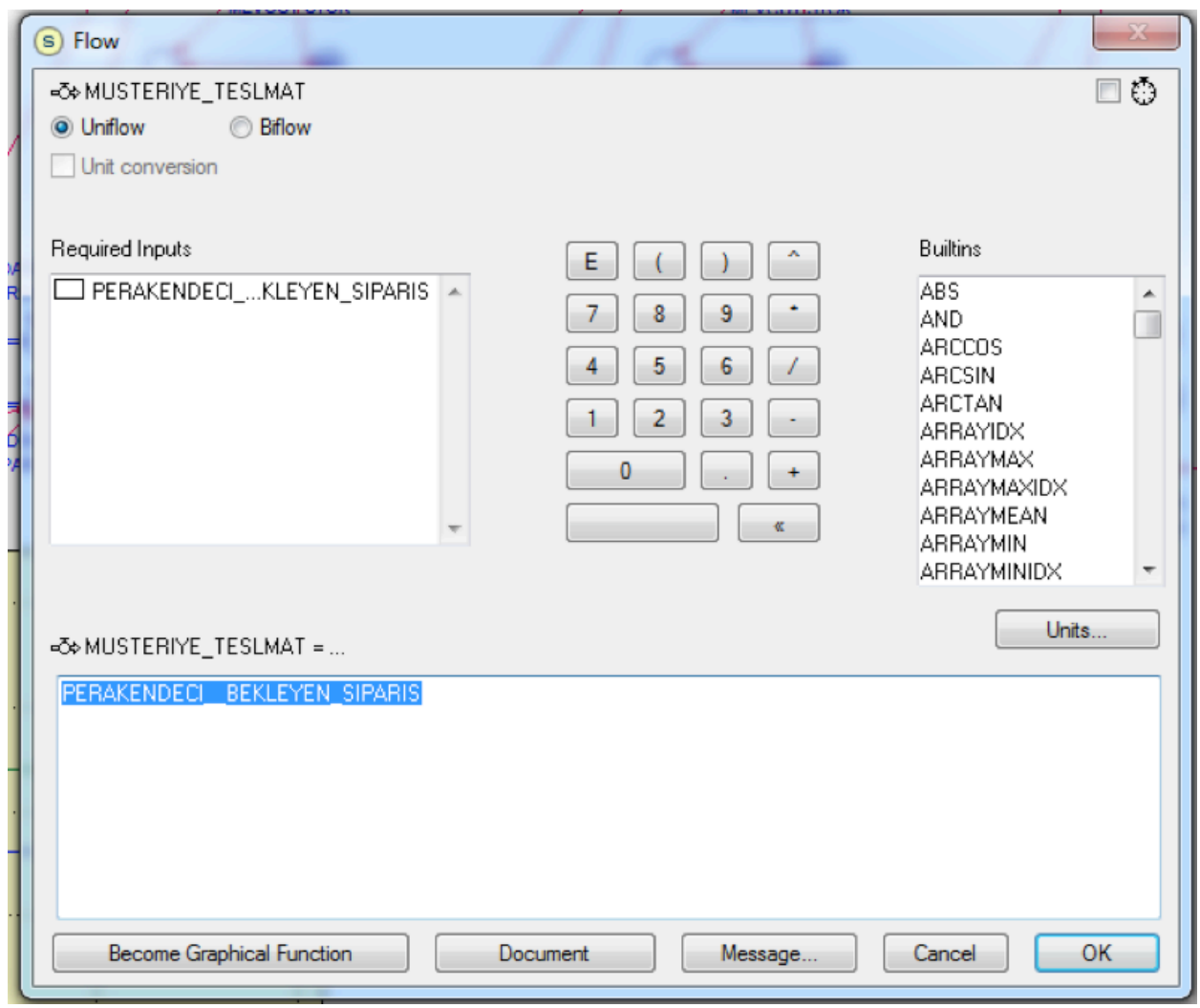

Şekil 2. Flow Bileşeni 


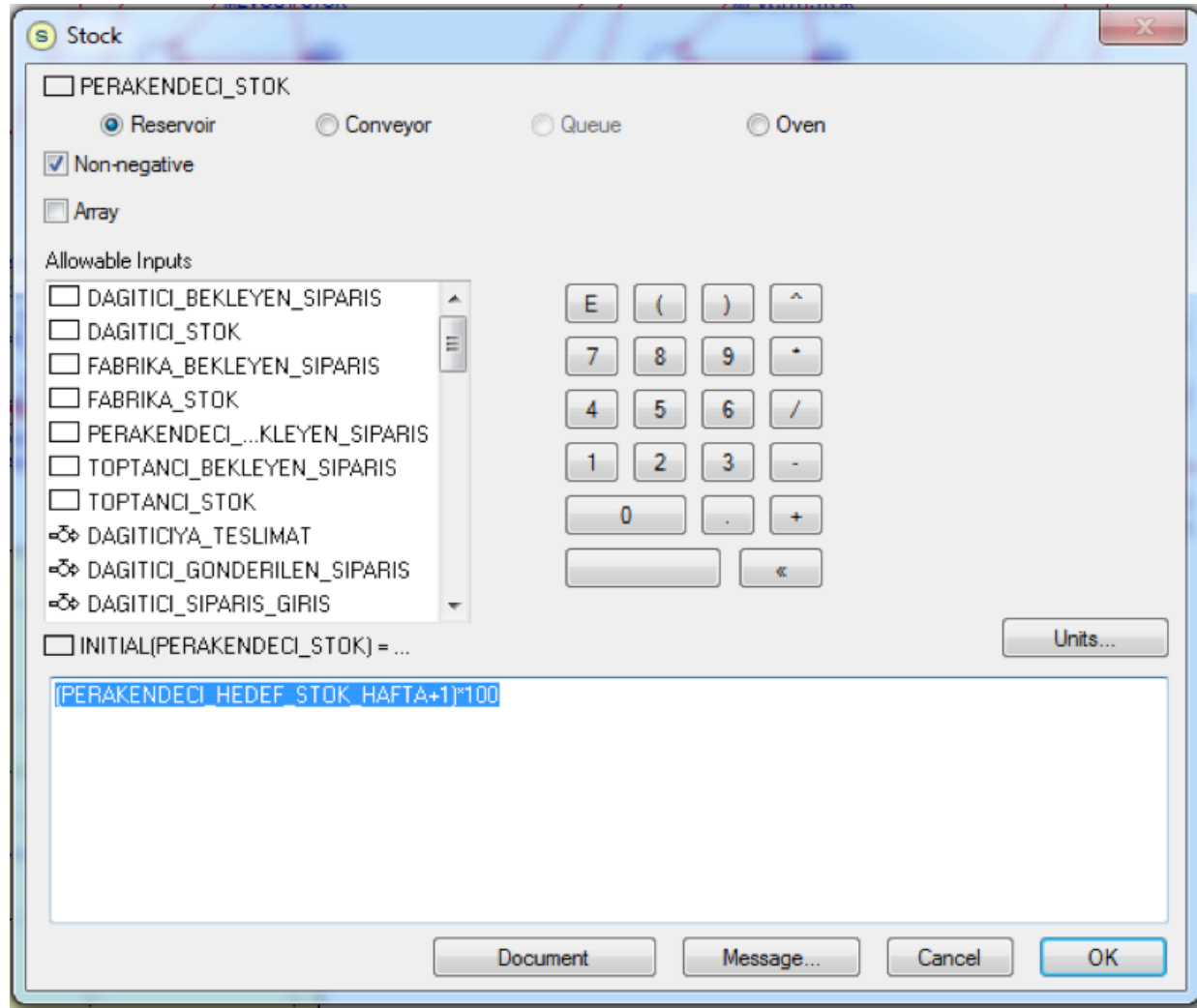

Şekil 3. Stock Bileşeni

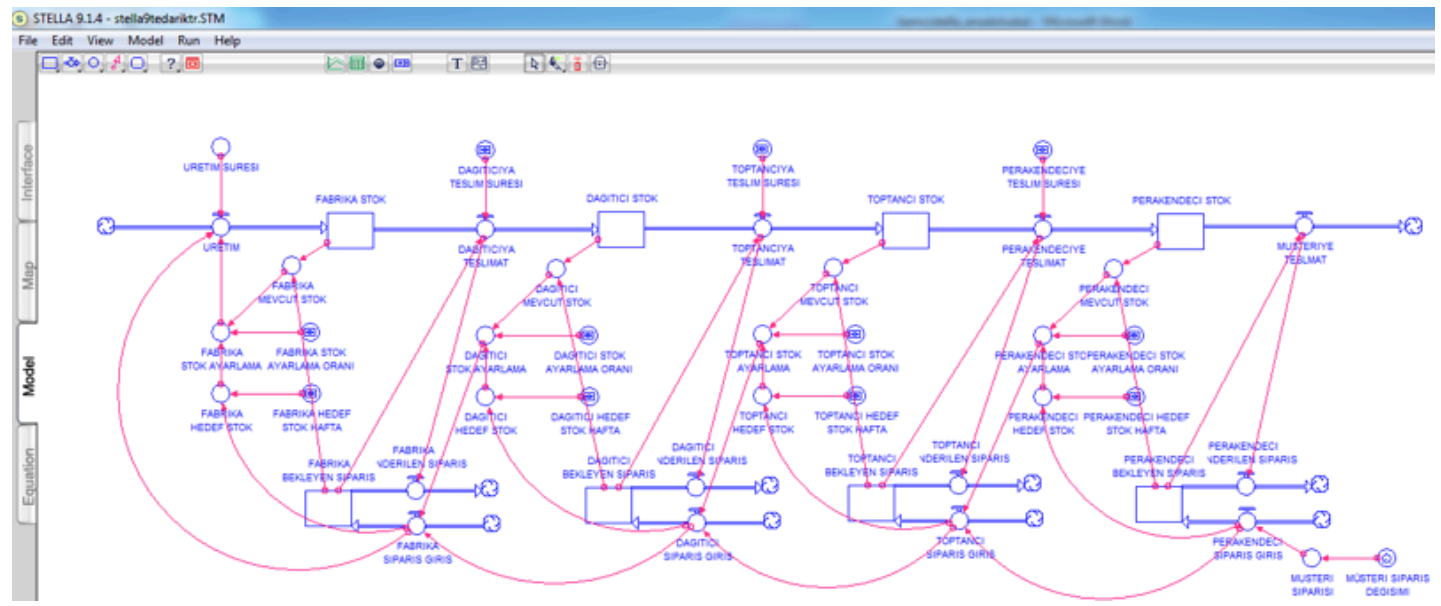

Şekil 4. Tedarik Zinciri Modeli 


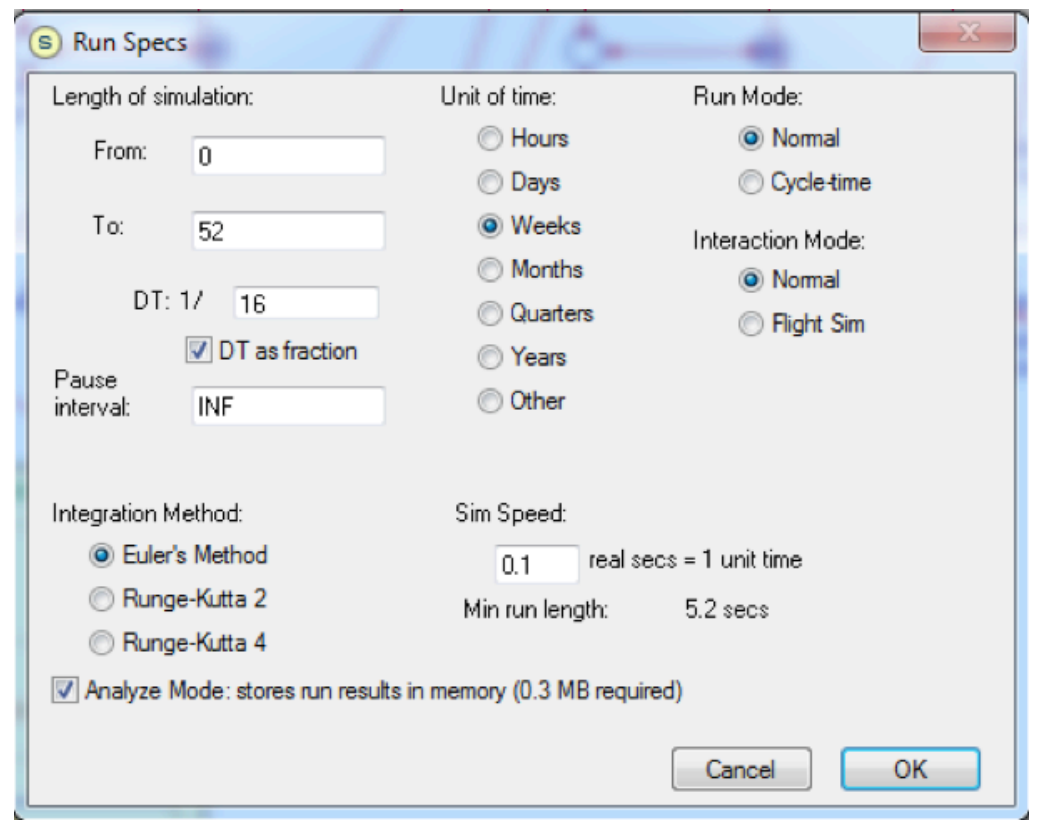

Şekil 5. "Run Specs" Penceresi

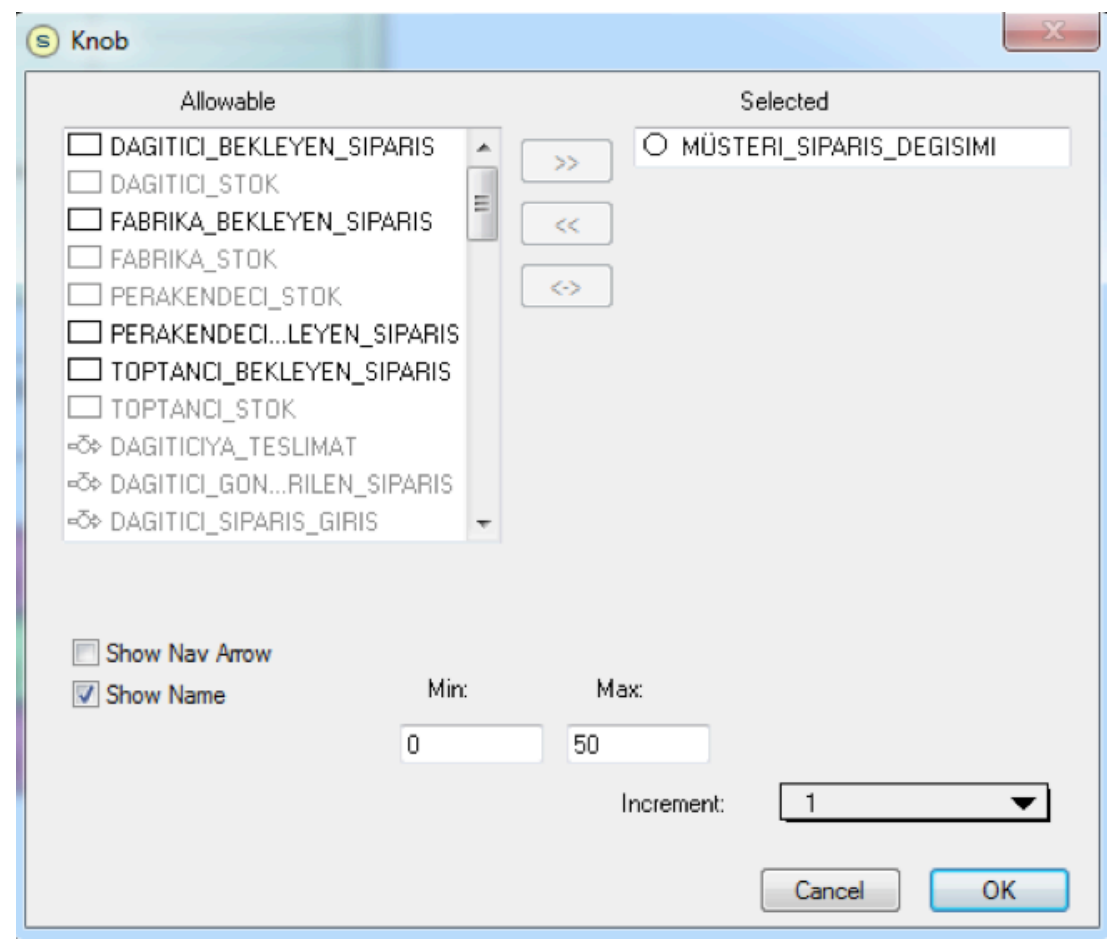

Şekil 6. "Knob Input Device" Penceresi 
Tedarik zincirinde yer alan her bir üye için hafta bazında hedef stok değerlerine ilişkin değişim aralıkları [0 hafta; 8 hafta], stok ayarlama oranlarına ilişkin değişim aralıkları $[0 ; 1]$ ve teslimat sürelerine ilişkin de- ğişim aralıkları [1 hafta; 8 hafta] olarak belirlenmiştir. Buna yönelik olarak toplam onbir adet "Slider Input Device" kullanılmıştır. Örnek "Slider Input Device" penceresi Şekil 7’de sunulmuştur.

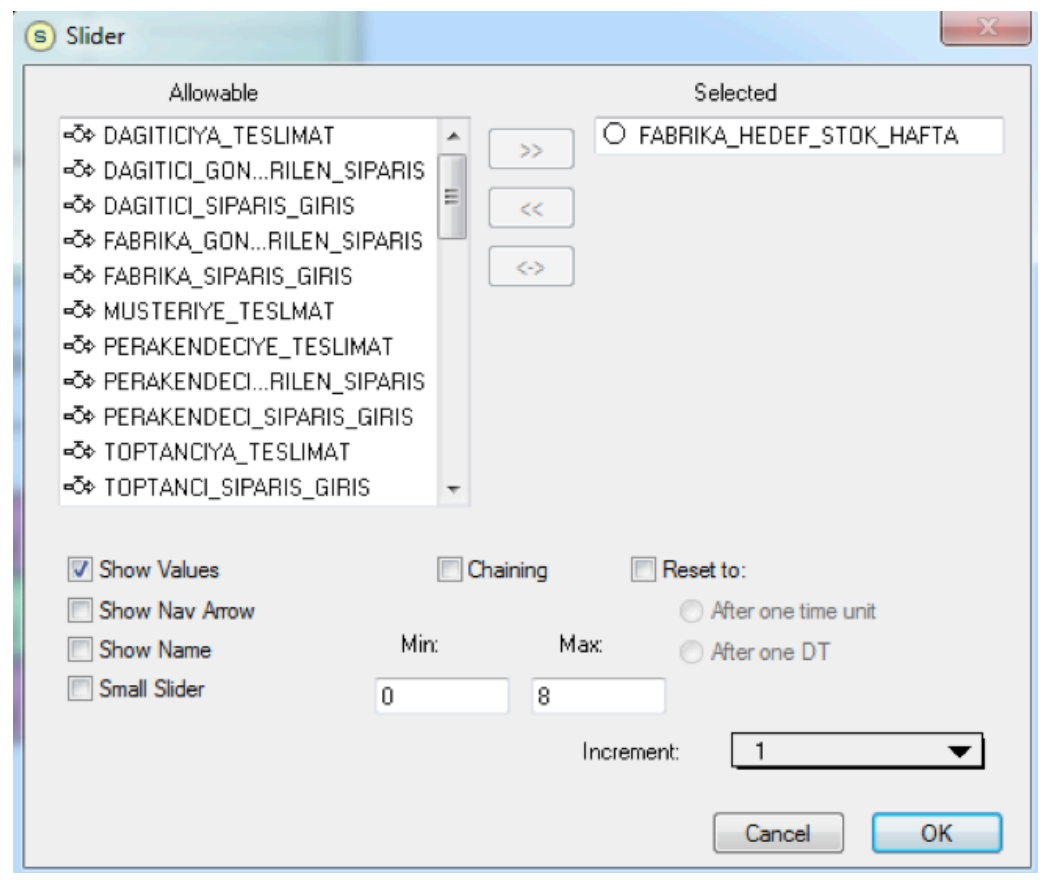

Şekil 7. Örnek "Slider Input Device" Penceresi

Bu düzenlemelerin ardından modeli test etmek amacıyla müşteri sipariş değişimi sıfır alınarak çalıştırılmış ve modelin anlamlı sonuçlar ürettiği görülmüştür. Müşteri talebi değişmediği için kamçı etkisi de simülasyon modeli sonuçlarında ortaya çıkmamış diğer bir deyişle stok dalgalanmaları meydana gelmemiştir. Bu işlemin devamında simülasyon modeli farklı senaryolara göre çalıştırılıp tedarik zincirinde- ki her bir üyeye ilişkin stok düzeyleri kaydedilmiştir. Örnek olarak, başlangıçta 100 adet olan talebin 5. Haftadan itibaren 108 adet olduğu ve stok ayarlama oranının her bir üye için \%50 olarak değiştirildiği modele ilişkin stok kayıtları Tablo 5’te, başlangıçta 100 adet olan talebin 5. Haftadan itibaren 108 adet olduğu diğer değişkenlerin başlangıç değerinde tutulduğu modele ilişkin stok değerleri ise Şekil 8'de verilmiştir. 
Tedarik Zincirinde Kamçı Etkisini Oluşturan Faktörlerin Simülasyon Programı ile Analizi

\section{Tablo 5. Örnek Stok Değişim Kayıtıarı}

\begin{tabular}{|c|c|c|c|c|}
\hline Zaman & Dağıtıcı Stok & Fabrika Stok & Perakendeci Stok & Toptanc1 Stok \\
\hline 0 & 300,00 & 300,00 & 300,00 & 300,00 \\
\hline 1 & 300,00 & 300,00 & 300,00 & 300,00 \\
\hline 2 & 300,00 & 300,00 & 300,00 & 300,00 \\
\hline 3 & 300,00 & 300,00 & 300,00 & 300,00 \\
\hline 4 & 300,00 & 300,00 & 300,00 & 300,00 \\
\hline 5 & 300,00 & 300,00 & 300,00 & 300,00 \\
\hline 6 & 313,75 & 410,54 & 303,13 & 306,56 \\
\hline 7 & 343,23 & 443,20 & 309,85 & 320,63 \\
\hline 8 & 365,03 & 405,31 & 316,41 & 332,72 \\
\hline 9 & 368,09 & 343,51 & 321,08 & 338,33 \\
\hline 10 & 355,65 & 295,90 & 323,67 & 337,86 \\
\hline 11 & 337,40 & 276,65 & 324,71 & 333,99 \\
\hline 12 & 321,91 & 281,20 & 324,86 & 329,38 \\
\hline 13 & 313,30 & 297,46 & 324,65 & 325,71 \\
\hline 14 & 311,45 & 314,55 & 324,37 & 323,54 \\
\hline 15 & 313,99 & 326,44 & 324,15 & 322,69 \\
\hline 16 & 318,13 & 331,82 & 324,02 & 322,69 \\
\hline 17 & 321,90 & 332,19 & 323,97 & 323,06 \\
\hline 18 & 324,36 & 329,96 & 323,96 & 323,49 \\
\hline 19 & 325,46 & 327,14 & 323,97 & 323,82 \\
\hline 20 & 325,57 & 324,89 & 323,98 & 324,01 \\
\hline 21 & 325,18 & 323,58 & 323,99 & 324,09 \\
\hline 22 & 324,66 & 323,10 & 324,00 & 324,09 \\
\hline 23 & 324,23 & 323,15 & 324,00 & 324,07 \\
\hline 24 & 323,97 & 323,42 & 324,00 & 324,04 \\
\hline 25 & 323,86 & 323,71 & 324,00 & 324,01 \\
\hline 26 & 323,85 & 323,93 & 324,00 & 324,00 \\
\hline 27 & 323,89 & 324,04 & 324,00 & 323,99 \\
\hline 28 & 323,94 & 324,08 & 324,00 & 323,99 \\
\hline 29 & 323,98 & 324,07 & 324,00 & 324,00 \\
\hline 30 & 324,00 & 324,05 & 324,00 & 324,00 \\
\hline 31 & 324,01 & 324,02 & 324,00 & 324,00 \\
\hline 32 & 324,01 & 324,01 & 324,00 & 324,00 \\
\hline 33 & 324,01 & 324,00 & 324,00 & 324,00 \\
\hline 34 & 324,00 & 323,99 & 324,00 & 324,00 \\
\hline 35 & 324,00 & 323,99 & 324,00 & 324,00 \\
\hline 36 & 324,00 & 324,00 & 324,00 & 324,00 \\
\hline 37 & 324,00 & 324,00 & 324,00 & 324,00 \\
\hline 38 & 324,00 & 324,00 & 324,00 & 324,00 \\
\hline 39 & 324,00 & 324,00 & 324,00 & 324,00 \\
\hline 40 & 324,00 & 324,00 & 324,00 & 324,00 \\
\hline 41 & 324,00 & 324,00 & 324,00 & 324,00 \\
\hline 42 & 324,00 & 324,00 & 324,00 & 324,00 \\
\hline 43 & 324,00 & 324,00 & 324,00 & 324,00 \\
\hline 44 & 324,00 & 324,00 & 324,00 & 324,00 \\
\hline 45 & 324,00 & 324,00 & 324,00 & 324,00 \\
\hline 46 & 324,00 & 324,00 & 324,00 & 324,00 \\
\hline 47 & 324,00 & 324,00 & 324,00 & 324,00 \\
\hline 48 & 324,00 & 324,00 & 324,00 & 324,00 \\
\hline 49 & 324,00 & 324,00 & 324,00 & 324,00 \\
\hline 50 & 324,00 & 324,00 & 324,00 & 324,00 \\
\hline 51 & 324,00 & 324,00 & 324,00 & 324,00 \\
\hline Final & 324,00 & 324,00 & 324,00 & 324,00 \\
\hline
\end{tabular}




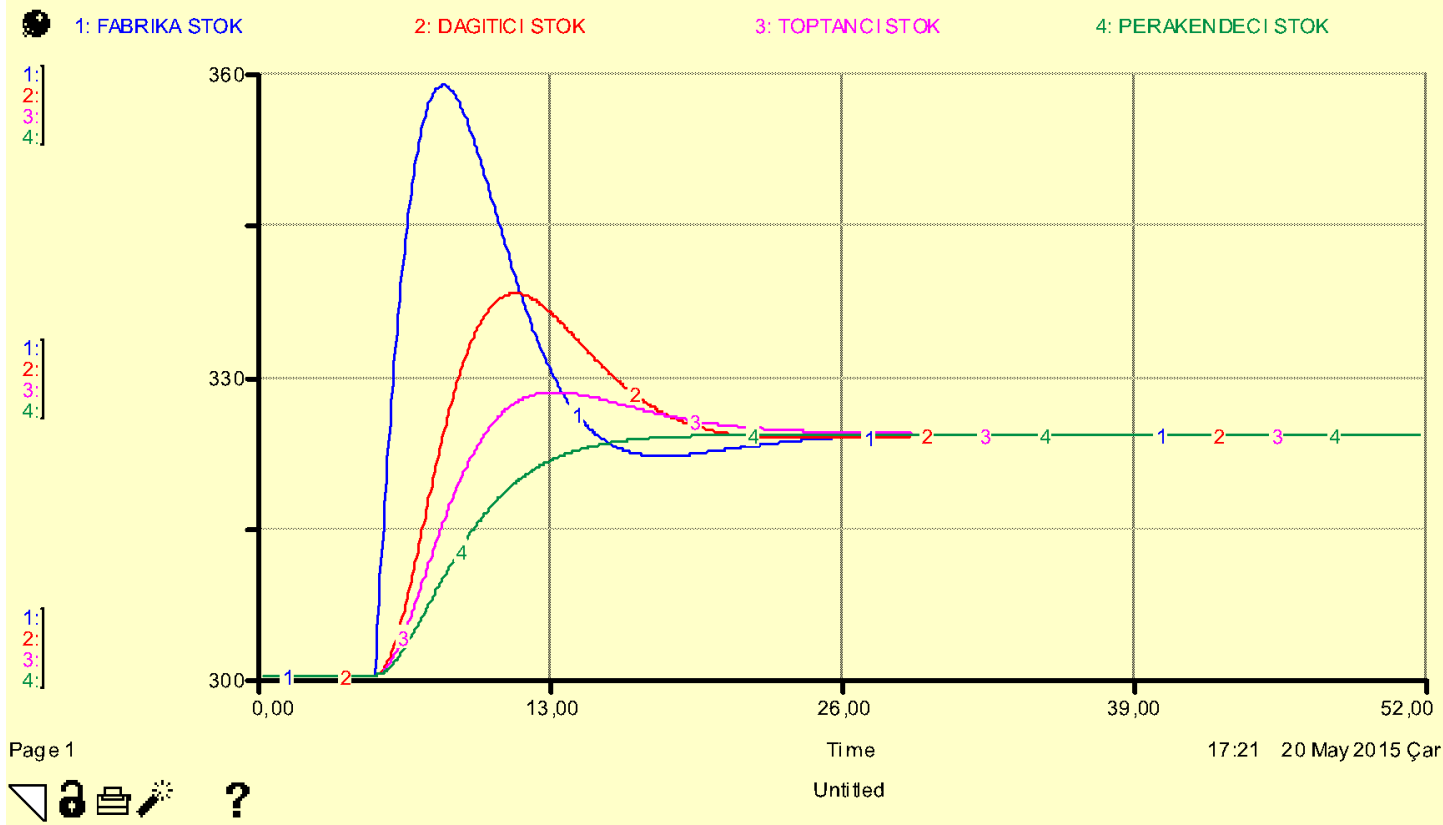

Şekil 8. Örnek Stok Değişim Grafiği

Tablo 5'teki değerler incelendiğinde, perakendecinin müşteri talebinde meydana gelen değişimden en az etkilendiği stok değişim aralığının çok dar olduğu anlaşılmaktadır. Üreticinin stok değerlerine göz atıldığında ise başlangıçta 300 olan stok seviyesinin müşteri talebindeki değişime bağlı olarak uzun vadede 324 değerinde sabitlenmesi gerekirken 276 ile 443 aralığında dalgalandığ 1 görülmektedir. Başlangıçta 100 adet olan talebin 5. Haftadan itibaren 108 adet olduğu diğer değişkenlerin başlangıç değerinde tutulduğu modele ilișkin stok değerlerini gösteren Șekil 8 'de de aynı dalgalanma rahatlıkla görülebilmektedir. Bu senaryoya göre üreticinin stok düzeyi 315 ile 360 aralığında dalgalanmaktadır.

Uygulanan diğer senaryolarda yapılan değişiklikler ve stok düzeylerindeki etkileri ile ilgili önemli noktalar şu şekilde ifade edilebilir. Tedarik zincirindeki her bir unsurun hedef stok düzeyleri 2 hafta yerine 3 hafta olarak değiştirildiğinde fabrika stok seviyesinin 500 değerini aştığı ve uzun vadede stokların 432 değerinde sabitlendiği görülmüştür. Talep 100 birimden 108 birime çıkarken tedarik zincirinde yer alan fabrika, dağıtıcı, toptancı ve perakendecinin hedef stok seviyesi 4 hafta yapıldığında fabrika stoğu 672 değerine ulaşmakta ve uzun vadede tüm zincir üyele- rinin stoklar1 540 değerinde sabitlenmektedir. Diğer değişkenler sabit kalmak koşuluyla (ceteris paribus) fabrikadan dağıtıcıya, dağıtıcıdan toptancıya ve toptancidan perakendeciye teslimat süreleri 3 hafta yapıldığında kamçı etkisinin çok daha şiddetli olduğu görülmektedir. Bu senaryoda fabrika stok seviyesi 283 ile 1185 arasında ciddi biçimde dalgalanmaktadır. Diğer değişkenler sabit kalmak koşuluyla (ceteris paribus) müşteri talebindeki değişim 25 birim olduğunda, diğer bir deyişle talep 100 birimden 125 birime yükseldiğinde kamçı etkisinin çok az olduğu görülmekte ve kamçı etkisinden doğal olarak en fazla etkilenen fabrikanın stoklarının en fazla 483 olduğu görülmektedir.

\section{Sonuç}

Tüketicilerin giderek çeşitlenen istek ve ihtiyaçlarını karşılayan mal ve/veya hizmetleri tek bir firmanın üretebilmesi mümkün değildir. Örnek vermek gerekirse, otomobil üretimi için ürün ağacı hazırlandığında, lastikten kaportaya, pencerelerden vites mekanizmasına kadar binden fazla farklı bileşenin montaj işleminin yapılması gerekmektedir. Otomotiv firmasının bu bileşenlerin hepsini üretmek için yatı- 
rım yapması anlamlı olmamaktadır. Ayrıca ürün tek bir firmada üretilebilse bile müşterinin ayağına gitmek gerektiğinden bir satış ve dağıtım kanalının kullanılması mecburidir. İște tüm bu nedenlerden dolayı tedarik zinciri yapısının bulunması kaçınılmazdır. $\mathrm{Bu}$ yapı içerisinde müşteriden gerekli bilgiyi toplamak ve müşteri istek ve ihtiyaçlarını zamanında karşılayabilmek ise çok zorlu bir süreçtir. Bilgi zincir boyunca aktıkça bozulmakta ve kamçı etkisi olarak literatürde yerini alan stok dalgalanmalarına yol açmaktadır. $\mathrm{Bu}$ çalışma kapsamında, kamçı etkisi ile ilgili literatürde yer alan güncel çalışmalara örnekler verilmiştir. Ardından tedarik zinciri oyunu hakkında bilgi verilerek perakendeci, toptanc1, dağıtıcı ve üretici olmak üzere dört üyesi bulunan bir tedarik zinciri için dört kişilik bir ekiple oyun denenmiş ve yapılan teslimat, dönem başı stok, dönem sonu stok, karşılanamayan sipariş değerleri müşteri talebinde meydana gelen değişmeye göre incelenmiştir. Sipariş kararları verilirken birbirileri ile zitlaşan iki temel maliyet unsuru olan stoklama ve stoksuzluk maliyetleri esas alınmış ve zincirin her bir üyesinin kendi firması açısından toplam maliyeti en küçükleyecek şekilde karar vermesi hedeflenmiştir. Oyundan elde edilen sonuçlar kamçı etkisini açıkça göstermiş ve bu yapı Stella simülasyon programında tedarik zinciri modeli oluşturmak için baz alınmıştır. Stella simülasyon programında modelin kuruluş aşamaları açıklanmış ve müşteri siparişinde değişme olmaması durumuna göre çalıştırılarak test edilmiştir. Test aşamasının ardından model farklı senaryoların analizi için çalıştırılmış ve tedarik zincirindeki her bir üyenin stok değişimleri kaydedilmiştir. Senaryo analizlerinde kamçı etkisini belirleyen faktörler olarak zincirdeki tüm üyeler için malın siparişinden teslim alınmasına kadar geçen süreler, zincir üyelerinin stok politikaları ve müşteri siparişindeki değişim ele alınmıştır. Çalıştırılan senaryolardan, malın siparişinden teslim alınmasına kadar geçen sürelerin kısalmasının kamçı etkisini azaltabileceği sonucuna ulaşılmıştır. Bunun yanında stok politikalarındaki değişimlerin de kamçı etkisini değiştirdiği görülmüştür. Stok ayarlama oranının zincirin her üyesi için \%25’e düşürüldüğü senaryolarda da kamçı etkisinin dolayısıyla stok dalgalanmalarının azaldığı tespit edilmiştir. Stok ayarlama oranının uygulamaya geçirilmesi zaman serisi öngörümleme yöntemlerinden biri olan hareketli ortalama yöntemi ile yapılmaktadır. Dört dönemlik hareketli ortalama değerine göre sipariş kararı verilmesi, talepteki ani artışlara karşı anlık tepki verilmemesi ve soğukkanlı hareket edilmesini sağlamakta ve stok dalgalanmalarını azaltmaktadır.

\section{Kaynakça}

Ali, M. M. Babai, M. Z. Boylan, J. E. Syntetos, A. A. (2015). On The Use ff Simple Moving Averages For Supply Chains Where Information is not Shared. IFAC-Papers OnLine, 48-3, 1756-1761.

Babai, M.Z. Boylan, J.E. Syntetos, A.A., Ali, M.M. (2015). Reduction of The Value of Information Sharing As Demand Becomes Strongly Autocorrelated. International Journal of Production Economics, http://dx.doi.org/10.1016/j.ijpe.2015.05.005 (baskıda makale).

Blos, M. F. Da Silva, R. M. Miyagi, P. E. (2015). Application of An Agent-Based Supply Chain To Mitigate Supply Chain Disruptions. IFAC-Papers OnLine, 48-3, 640-645.

Cannella, S. Framinan, J. M. Bruccoleri, M. BarbosaPóvoa, A. P., Relvas, S. (2015). The Effect of Inventory Record Inaccuracy in Information Exchange Supply Chains. European Journal of Operational Research, 243, 120-129.

Costantino, F. Gravio, G.D. Shaban, A., Tronci, M. (2015a). The Impact of Information Sharing on Ordering Policies To Improve Supply Chain Performances. Computers \& Industrial Engineering, $82,127-142$.

Costantino, F. Gravio, G.D. Shaban, A., Tronci, M. (2015b). A Real-Time SPC Inventory Replenishment System To Improve Supply Chain Performances. Expert Systems with Applications, 42, 1665-1683.

Costantino, F. Gravio, G.D. Shaban, A., Tronci, M. (2015c). SPC Forecasting System To Mitigate The Bullwhip Effect and Inventory Variance in Supply Chains. Expert Systems with Applications, 42, 1773-1787.

Costas, J. Ponte, B. Fuente, D.d.l. Pino, R., Puche, J. (2015). Applying Goldratt's Theory of Constraints To Reduce The Bullwhip Effect Through AgentBased Modeling. Expert Systems with Applications, 42, 2049-2060.

Dominguez, R. Cannella, S., Framinan, Jose M. (2015a). The Impact of The Supply Chain Structure on Bullwhip Effect. Applied Mathematical Modelling, (baskıda makale). 
Dominguez, R. Cannella, S., Framinan, Jose M. (2015b). On Returns and Network Configuration in Supply Chain Dynamics. Transportation Research Part E, 73, 152-167.

Duan, Y. Yao, Y., Huo, J. (2015). Bullwhip Effect Under Substitute Products. Journal of Operations Management, 36, 75-89.

Editorial. (2015). System Dynamics Perspectives and Modeling Opportunities For Research in Operations Management. Journal of Operations Management, (baskıda makale).

Fu, D. Ionescu, C. Aghezzaf, E-H., Keyser, R. D. (2015). Quantifying and Mitigating The Bullwhip Effect in A Benchmark Supply Chain System by An Extended Prediction Self-Adaptive Control Ordering Policy. Computers \& Industrial Engineering, 81, 46-57.

Göksu, A. Kocamaz, U. E. Uyaroğlu, Y. (2015). Synchronization and Control of Chaos in Supply Chain Management. Computers \& Industrial Engineering, 86, 107-115.

Hosoda, T. Disney, S. M., Gavirneni, N. (2015). The Impact of Information Sharing, Random Yield, Correlation, and Lead Times in Closed Loop Supply Chains. European Journal of Operational Research, doi: 10.1016/j.ejor.2015.05.036. (baskıda makale).

http://www.beergame.org , 27.05. 2015

Jeng, D. J-F. (2015). Generating A Causal Model of Supply Chain Collaboration Using The Fuzzy DEMATEL Technique. Computers \& Industrial Engineering, 87, 283-295.

Lee, J. Cho, H., Kim, Y. S. (2015). Assessing Business Impacts of Agility Criterion and Order Allocation Strategy in Multi-Criteria Supplier Selection. Expert Systems with Applications, 42, 1136-1148.

Ma, Y. Wang, N. He, Z. Lu, J., Liang, H. (2015). Analysis of The Bullwhip Effect in Two Parallel Supply Chains with Interacting Price-Sensitive Demands. European Journal of Operational Research, 243, 815-825.
Mackelprang, A. W., Malhotra, M. K. (2015). The Impact of Bullwhip on Supply Chains: Performance Pathways, Control Mechanisms, and Managerial Levers. Journal of Operations Management, 36, 15-32.

Mangan, J. Lalwani, C., Butcher, T. (2008). Global Logistics And Supply Chain Management, New Jersey: John Wiley \& Sons Ltd.

Masten, K. A. Kim, S-L. (2015). So Many Mechanisms, So Little Action: The Case For 3rd Party Supply Chain Coordination. International Journal of Production Economics, 168, 13-20.

Murray, P. W. Agard, B. Barajas, M. A. (2015). Forecasting Supply Chain Demand By Clustering Customers. IFAC-PapersOnLine, 48-3, 1834-1839.

Nagaraja, C. H. Thavaneswaran, A., Appadoo, S. S. (2015). Measuring The Bullwhip Effect for Supply Chains with Seasonal Demand Components. European Journal of Operational Research, 242, 445-454.

Qiu, X. Yu, L., Zhang, D. (2015). Stabilization of Supply Networks with Transportation Delay and Switching Topology. Neurocomputing, 155, 247-252.

Sterman, J. D. Doğan, G. (2015). "I’m not hoarding, I'm just stocking up before the hoarders get here." Behavioral causes of phantom ordering in supply chains. Journal of Operations Management, (bask1da makale).

Udenio, M. Fransoo, J. C., Peels, R. (2015). Destocking, The Bullwhip Effect, and The Credit Crisis: Empirical Modeling of Supply Chain Dynamics. International Journal of Production Economics, 160, 34-46.

Wang, Z. Wang, X., Ouyang, Y. (2015). Bounded Growth of The Bull-Whip Effect Under A Class of Nonlinear Ordering Policies. European Journal of Operational Research, doi: 10.1016/j. ejor.2015.04.047 (baskıda makale).

Xu, K. Dong, Y. Xia, Y. (2015). 'Too Little’ or 'Too Late': The Timing of Supply Chain Demand Collaboration. European Journal of Operational Research, 241, 370-380.

Zhao, Y., Zhao, X. (2015). On Human Decision Behavior in Multi-Echelon Inventory Management. International Journal of Production Economics, 161, 116-128. 